\title{
ROMUNISME DALAM PERGUMULAN WACANA IDEOLOGI MASTUMI
}

\author{
Oleh: Samsuri
}

\section{Abstract}

This article explores the relationship between Islam and communism in Indonesia, which could be learnt from the political-ideological struggle of Masyumi and PKI (Indonesian Communist Party) in the parliamentary democracy era. The ideological discourse of Masyumi on the Communism was supported by ideological setting when its establishment in the revolution nature and the politic ideological competition after the proclamation of independence on $\mathrm{Au}$ gust 17, 1945, and the international situation of the Cold War. The nature of ideological setting was translated in the explaining system such as ideological interpretation of Islam by comparing Islamic superiority over capitalism and communism; religious-socialism and Marxian-socialism issues; and the fatwa (legal decisions) of anti-communism that crystallized in the Masyumi factions when they faced the communism issues.

\section{المنال)}

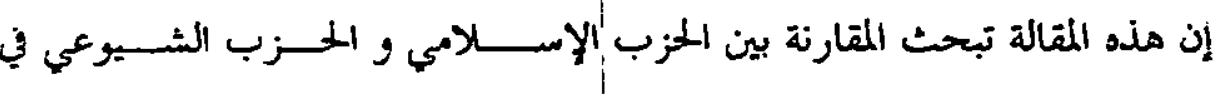

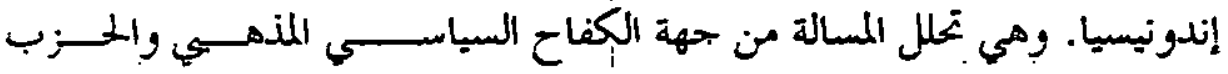
الثيرعي الإندونيسي في زمن الديمقراطية اليرلمانية. الفرق الملنهيي ين ماثـومي و الملزب الثيوعي الإندونيسي هدةا المحالة المنهبية عند فضتها في الثورة والمباراة

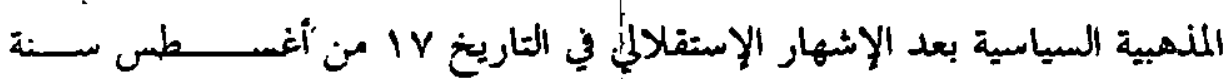

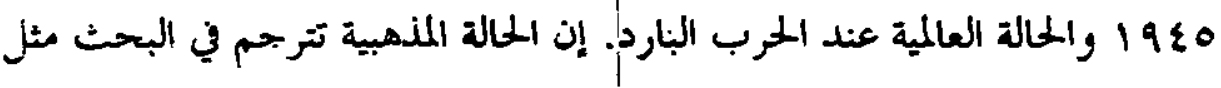

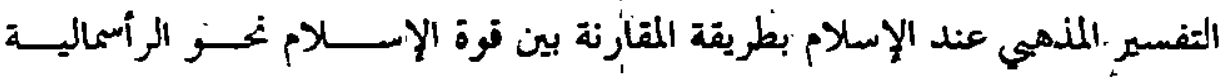
والثيوعية, الالشتراكية الدينية و ماركسية. 


\section{A. Pendahuluan}

Pergumulan Islam dan Komunisme di Indonesia telah mewarnai perjalanan sejarah modern bangsa ini. Sejak komunisme mulai berkembang pada sekitar 1916-1920 hubungan lama yang menyejarah antara Islam dan Komunisme, baik di masa revolusi fisik ataupun di periode sesudahnya, telah banyak menyita perhatian kajian banyak akademisi. ${ }^{1}$

Di masa sekarang, polemik pro-kontra terutama di kalangan Islam tentang komunisme menjadi daya tarik tersendiri untuk dikaji di era pasca Perang Dingin. ${ }^{2}$ Pro-kontra tersebut diperkuat setelah di lima tempat yang berbeda Presiden Abdurrahman Wahid menyatakan permohonan maaf pada awal 2000 terhadap orang-orang yang menjadi korban penumpasan peristiwa G30S/ PKI, serta usulan agar larangan terhadap ajaran Komunisme yang tercantum di dalam Ketetapan MPRS No. XXV Tahun 1966 dicabut. $^{3}$

Ketetapan (Tap) MPRS No. XXV/MPRS/1966 memuat pernyataan sebagai organisasi terlarang di seluruh wilayah Negara Republik Indonesia bagi Partai Komunis Indonesia, dan larangan setiap kegiatan untuk menyebarkan atau mengembangkan pabam atau ajaran Komunisme/Marxisme-Leninisme. Ada dua alasan PKI dan paham Komunisme/Marxisme-Leninisme dilarang. Pertama, paham komunisme/Marxisme-Leninisme dinyatakan bertentangan dengan Pancasila, terutama jika dihubungkan dengan sila kesatu Pancasila. Kedua, orang-orang dan golongan penganut paham tersebut, khususnya PKI pada 1948 dan 1965, dikatakan telah beberapa kali berusaha merobohkan kekuasaan Pemerintah Republik Indonesia yang sah dengan jalan kekerasan. ${ }^{4}$ Sikap pro-kontra di kalangan Islam terhadap Komunisme sebenarnya dapat dipelajari kembali dari perjalanan politik di Indonesia pasca-kemerdekaan hingga akhir era demokrasi liberal (1957). Selama era demokrasi liberal

\footnotetext{
' Kajian akademik hubungan antara Islam dan Komurisme di Indonesia ini antara lain, untuk menyebut beberapa nama, dapat dicermati dalam Timur Jaylani, 1959, The Sarekat Islam Moventent: Its Contribution to Indonesian Narionalism, Tesis MA di Montreal: McGill University. H. J. Benda dan Ruth T. McVey (penyunting dan penerjemah). 1960. The Communist Uprisings of 1926-1927 in Indonesia: Key Documents, Comell University Press, Ithaca. Deliar Noer, 1960, Masjumi: Its Organization, Ideology, and Political Role in Indonesia, Tesis MA di Comell University, Ithaca. Amold C. Brackman, 1963, Indonesian Communism: A History, Frederick A. Praeger, New York. Ruth T. McVey, 1965, The Rise of Indonesian Communism, Comell University Press, Ithaca. Takashi Siraishi, 1997, Zaman Bergerak: Radikalisme Rakyat di Jawa 1912-1926, alih bahasa Hilmar Farid Grafiti Press, Jakarta. Lihat juga Soe Hok Gie, 1999, Di Bawah Lentera Merah: Riwayat Sarekat Islam Semarang 1917-1920, Yayasan Bentang Budaya, Yogyakarta.

2 Pendapat pro dan kontra dapat dibaca antara lain dalam "Seputar Penghapusan Tap MPRS No XXV", Suara Merdeka, 8 April 2000, hal. XI.

${ }^{3}$ Permohonan maaf Presiden Abdurrahman Wahid tersebut disampaikan pada forum-forum: "Secangkir The Bersama Gus Dur" di TVRI, 14 Maret 2000); dialog dengan masyarakat usai shalat jumat di Masjid AlMunawatoh, Ciganjur, 22 Maret 2000. Pertemuan dengan masyarakat Jawa Timur di Malang, 25 Maret 2000. Pembukaan Kongres PDI Perjuangan di Semarang, 27 Maret 2000. Dan tatap muka dengan masyarakat Kedung Ombo, 3 Mei 2000.Lihat juga Eriyanto, 2001, "Sikap Mendua pada Gus Dur," Jumal Pantau, ediși 10, hal, 11. 96.

4 Lihat, Keputusan2 M.P.R.S. Sidang Umum ke-IV 20 Djuni - 6 Djuli 1966, U.P. Indonesia. Yogyakarta, hal.
} 
tersebut terdapat pergumulan penting yang dilakukan oleh kelompok Muslim dengan kelompok komunis (selain dengan sosialis ataupun nasionalis).

Sistem kepartaian yang mendukung kehidupan demokrasi liberal mendapatkan ruang geraknya setelah Maklumat Pemerintah yang ditandatangani Wakil Presiden Republik Indonesia Mohammad Hatta, dikeluarkan pada 3 November 1945, tentang pembentukan partai-partai di Indonesia. Melalui maklumat itulah lahir partai-partai politik yang mewakili berbagai aliran ideologi-politik yang tumbuh di masyarakat. ${ }^{5}$

Bagi umat Islam, maklumat tersebut merupakan peluang untuk membentuk partai politik Islam. Kemudian dibentuklah Partai Masyumi yang direncanakan sebagai satu-satunya partai politik Islam berdasarkan keputusan Konggres Umat Islam di Yogyakarta, 7-8 November $1945 .^{6}$

Sebelumnya pernah berdiri Masyumi "buatan Jepang" pađa bulan Oktober 1943.7 Berbeda dengan Masyumi "buatan Jepang” yang oleh Pemerintah Pendudukan Jepang dijadikan alat untuk mengkooptasi umat Islam demi kepentingannya sendiri, Masyumi hasil Kongres Yogyakarta motif pembentukannya adalah untuk menjadikannya sebagai "partai politik tunggal" Islam yang dapat menyalurkan aspirási politik umat. ${ }^{8}$

Suasana revolusi yang sedang bergolak di Indonesia pada awal-awal kemerdekaan, dan persaingan dengan berbagai kelompok ideologi - yaitu Nasionalisme dan Marxisme/Sosialisme dari partai-partai baru tersebut telah mendorong tokoh-tokoh politik dan pergerakan sosial keagamaan Islam Indonesia yang telah aktif semenjak zaman pergerakan nasional untuk membentuk "partai tunggal" Islam di Indonesia. "Partai tunggal Islam" ini, yaitu Masyumi, akan menghimpun semua potensi kekuatan politik Islam. Dengan demikian, partai itu akan memiliki sifat pluralisme di dalamnya, tampak dari ragam aliran pemikiran keagamaan anggota-anggota Masyumi, seperti tercermin dalam susunan federatif keanggotaan istimewa yang terdiri atas organisasi sosial keagamaan, yaitu Muhammadiyah, Nahdlatul Ulama

\footnotetext{
S Partai-partaj tersebut antara lain: Masyumi (Majelis Syura Muslimin Indonesia) berdiri 7 November 1945; PKI (Partai Komunis Indonesia) berdiri tanggal 7 November 1945, sebelumnya telat didirikan kembali pada 21 Oknober 1945; Partai Rakyat Jelata berdiri 8 November 1945; Partai Kristen Indonesia (Parkindo), berdiri 10 November 1945; Partai Sosial Indonesia, berdio 10 November 1945; Partai Rakyat Sosialis, berdiri 20 November 1945: Partaj Katolik Repubtik Indonesia, berdiri 8 November 1945; Persanuan Rakyat Marthaen Indonesia, berdiri 17 Desember 1945; dan PNI (Partai Nasional Indonesia), berdiri 29 Jamuari 1946 sebagai hasil fusi antara PRI (Parai Rakyat Indonesia), Gerindo (Gerakan Rakyat Indonesia), dan Serikat Rakyat Indonesia yang masing-masing berdiri pada bulan November dan Desember 1945. Lihat: Sekretariat Negara Republik Indonesia, 1985, 30 Tahun Indonesia Merdeka, Jilid I, PT Citra Lamtoro Gung Persada, Jakarta, hal. 55-56. Lihat juga George McTurnan Kahin, 1952, Nationalism and Revolution in Indonesia. Cornell University Press, Ithaca, hal. 156-161.

- Abu Barkat, 1951, "Peristiwa Penting Bagi Umat Islam Indonesia 17-8-1945 - 17-8-1951", Suara Partai Masjitmi, No. 8-9, Th. Ke-6, Agustus-September, bai. 14 dan 16. Lihat juga Ahmad Syafii Maarif, 1985, Islam dan Masalah Kenegaraan: Srudt tentang Percaturan dalam Konstituane, LP3ES, Jakarta, hal. 110

7 bid.

ausril Inza Mahendra, 1999, Modernisme don Fundamentalisme dalam Politik Islam: Perbandingan Parai Masyumi (Indonesia) dan Portai Jom-'at-i-IsI'm§ (Patiston), Penerbit Paramadina, Jakarta, hal. 62.
} 
(NU), Persatuan Islam (Persis), Persatuan Umat Islam (PUI), Al-Irsyad, Jam'iyatul Wasliyah, Al-Ittihadiyah dan Persatuan Ulama Seluruh Aceh (PUSA). ${ }^{9}$

Pandangan dasar modernisme Masyumi yang secara positif memandang pluralisme telah mendorong Masyumi untuk bersikap terbuka. Keterbukaan itu tampak dalam kesediaannya untuk bekerja sama dengan golongan lain dalam mencapai tujuan Masyumi. Kerja sama ini pada awalnya dilakukan secara luas dan tanpa batas, sehingga di zaman revolusi itu pun Masyumi bersedia juga bekerja sama dengan golongan Komunis beraliran Trotskyis di bawah pimpinan Tan Malaka. ${ }^{10}$

Kerja sama Masyumi dengan PKI, yaitu Komunis beraliran Stalinis di bawah kepemimpinan Muso, sedikit sekali. Pada waktu sekelompok orang PKI mencoba untuk merebut kekuasaan, yang dimulai dari Madiun pada 18 September 1948, para pemimpinnya mendesak rakyat untuk menentang "Kabinet Masyumi yang dipimpin oleh Perdana Menteri Hatta." Kaum Komunis menuduh bahwa Hatta dan tokoh-tokoh Masyumi adalah "borjuis" dan "antek imperialis Amerika". Menurut tokoh-tokoh Komunis, berharap kepada "kemurahan hati Amerika" dalam menyelesaikan sengketa Indonesia-Belanda adalah "harapan sia-sia", karena Amerika Serikat juga "imperialis". Satu-satunya jalan yang mungkin bagi Indonesia untuk menang melawan Belanda adalah “jika Indonesia bersekutu dengan Uni Soviet”. Negara Komunis ini, menurut Muso telah jelas "anti-imperialisme dan kolonialisme"."11

Perang pamflet dan perkelahian antara pendukung Masyumi dan pendukung FDR (Front Demokrasi Rakyat) ${ }^{12}$ yang beraliran Komunis dan dipimpin oleh Muso itu menjadi sengit setelah Agustus 1948. Akhirnya meletuslah "Pemberontakan Komunis di Madiun" pada 18 September 1948. Bendera Indonesia (merah putih) diturunkan dan digantikan dengan bendera merah "palu arit". Dalam pemberontakan itu beribu-ribu rakyat, polisi dan pasukan

\footnotetext{
9 Anggota asli Masyumi adalah NU, Muhammadiyah, PUI dan Perikatan Umat Islam. Dua organisasi yang disebutkan terakhir ini kemudian bergabung menjadi satu organisasi PUSI (Persatuan Umat Islam Indonesia). Persis, PUSA, dan Al-Jam'iyanul Washliyah, menjadi anggota istimewa pada tahun 1949. Al-Ittihadiyah pada tahun 1951. Pada akhirnya, NU kejuar sebagai anggota istimewa Masyumi dan menjadikan dirinya sebagai partai politik Islam baru pada tahun 1952, mengikut jejak Partai Sarekat Islam Indonesia (PSII) yang keluar sebelumnya pada bulan Juli 1947, sebagai akibat tidak puas dengan dominasi kaum modernis di dalam kepemimpinan Masyumi. Lihat Yusril Ihza Mahendra, Modernisme dan Fundontentalisme, hal. 183-184; dan Ahmad Syafii Maarif, Islam dan Masalah Kenegaraan, bal.115.

10 Yusril thza Mahendra, Modemisme dan Fundamenalisme, hal, 82.

"Ibid, hal. 82-83. Lihat pula uraian menarik tentang Muso dan Front Demokrasi Rakyat (FDR) dalam Pemberontakan Madiun inu sebagai reaksi terhadap Kabinet Hatra dan Masyumi, dalam Soe Hok Gie, 1997, OrangOrang di Persimpangan Kiri Jalan: Kisah Pemberontakan Madiun September 1948. Yayasan Bentang Budaya. Yogyakarta, hal. 161-231

12 Deliar Noer, 1987, Panai Islam di Pensas Nasional 1945-1965. PT. Pustaka Utama Grafiti, Jakarta, hal. 184. FDR ini terutama didukung oleh organisasi politik Sayap Kiri, antara lain Partai Sosialis Indonesia (ParsiAmir Sjarifuddin), Partai Buruh, dan PKI. Lihat, Soe Hok Gie, Orang-Orang di Persimpangan Kiri. hal. 215.
} 
yang anti Komunis mati terbunuh. ${ }^{13}$ Begitu juga banyak orang yang mendukung komunis ikut terbunuh.

Masyumi mengutuk keras pemberontakan FDR, dan menuduh kaum Komunis sebagai "pengkhianat terhadap bangsa dan negara". Sejak peristiwa itu pula, Masyumi mulai mengganti sikapnya dalam bekerja sama dengan kaum Komunis ke arah yang sangat rigid. Ada yang berdalih bahwa bekerja sama dengan "kaum anti-Tuhan, anti agama, dan anti demokrasi" tidak boleh dilakukan untuk selama-lamanya. ${ }^{14}$ Sikap-sikap permusuhan antara Masyumi dan kaum Komunis, yang kemudian ditujukan secara langsung kepada PKI, berlanjut hingga Masyumi itu terpaksa membubarkan diri pada tahun $1960 .{ }^{15}$ Sikap permusuhan Masyumi terhadap PKI antara lain ditujukan pada sikap politik PKI yang dianggap telah "menghalalkan segala cara", dan prinsipprinsip Komunisme yang dianut PKI berlawanan secara diametral dengan prinsip-prinsip keagamaan yang dianut Masyumi. Pernyataan bahwa PKI pada 1954 menerima Pancasila sebagai dasar negara, bagi Masyumi merupakan sesuatu hal yang aneh dan tidak mungkin sepenuh hati, karena Komunisme pada dasarnya tidak mengakui adanya Tuhan.

Dari uraian di atas, tulisan ini bermaksud; (1) mengeksplorasi latar ideologis pembentukan Masyumi; (2) gagasan-gagasan pokok wacana ideologi Masyumi tentang Komunisme; dan, (3) implikasi wacana ideologi Masyumi terhadap faksi-faksi di tubuh Masyumi dalam menyikapi bahaya komunisme.

\section{B. Latar Ideologis Pembentukan Masyumi}

Cara pandang terhadap sejarah sebuah gerakan, baik bersifat sosial, pendidikan, maupun politik, dengan melihat motif atau tujuan dan latar kondisi sosio-ideologi-politis gerakan tersebut adalah sangat penting. Dengan begitu, maka akan diketahui secara jelas bagaimana paradigma, asumsi nilai, pemikiran, dan ideologi untuk mencapai tujuan gerakan tersebut dibangun oleh para tokoh pendiri atau pengambil inisiatif.

Sejarah pembentukan Masyumi pun tidak terlepas dari motif dan faktorfaktor yang melatarinya. Suasana revolusi dan persaingan berbagai kelompok ideologi di Indonesia pasca proklamasi kemerdekaan, serta peran tokoh-tokoh yang mengambil insiatif turut mewarnai pembentukan Masyumi. "Partai Politik Islam Indonesia Masyumi" didirikan dan djikrarkan sebagai satusatunya partai politik Islam pada 7 November 1945 berdasarkan keputusan

13 Yusril Thza Mahendra, Modernisme dan Fundamentalisme, hal. 83-84;

${ }^{14}$ Ibid, hal. 84.

1s Deliar Noer, Panai Islam, hal. 184. Perintah resmi pembubaran Masyumi (dan Parta Sosialis Indonesia/PSI -Sjahrir) menurut Kepurusan Presiden No. 200/1960, pada 19 Agustus 1960, tentama karena keterlibatan beberapa tokoh penting Masyumi dan PSI dalam pemberontakan PRRI (Pemerintahan Revolusioner Republik Indonesia) di Sumarera Barat mulai Februari 1958. Lihat pula Ahmad Syafii Maarif, Islam dan Masalah Kenegaraan, hal.187192. 
Kongres Umat Islam di Yogyakarta yang diselenggarakan 7-8 November 1945, bertepatan 1-2 Dzulhijjah $1364 \mathrm{H}$. Inisiatif pembentukan Masyumi berasal dari sejumlah tokoh partai politik dan gerakan sosial keagamaan Islam sejak zaman pergerakan, ${ }^{16}$ seperti Agoes Salim, Professor Abdul Kahar Muzakkir, Abdul Wahid Hasjim, Mohammad Natsir, Mohammad Roem, Prawoto Mangkusasmito, Dr. Sukiman Wirjosandjojo, Ki Bagus Hadikusumo, Mohammad Mawardi, dan Dr. Abu Hanifah. ${ }^{17}$ Organisasi-organisasi para tokoh itu, ada yang meleburkan diri atau kemudian menjadi penopang utama sebagai anggota istimewa Masyumi. ${ }^{18}$

Keputusan membentuk Masyumi oleh sejumlah tokoh Islam itu, tidak sekadar sebagai keputusan tokoh-tokoh tersebut, tetapi keputusan dari "seluruh umat Islam Indonesia" melalui utusan wakil-wakil mereka. ${ }^{19}$ Penilaian ini adalah beralasan apabila Masyumi dilihat dari susunan kepengurusannya, yang mencerminkan wakil-wakil sejumlah partai politik dan gerakan sosial keagamaan Islam. Keterwakilan tokoh-tokoh berbagai organisasi Islam di Masyumi, mencerminkan sifat pluralisme sebagai "partai tunggal Islam" yang menghimpun semua potensi kekuatan politik Islam. Motif itu, menurut Yusril Ihza Mahendra, didorong oleh pandangan-pandangan dasar modernisme yang positif dan optimis memandang pluralisme. ${ }^{20}$ Perbedaan dipandang sebagai "rahmat" dari Tuhan, karena perbedaan itu "tidak bersifat fundamental", tetapi hanya berhubungan dengan masalah-masalah furãiyah (perkara-perkara kecil). ${ }^{21}$ Tidaklah mengherankan, apabila pada akhirnya tokoh-tokoh tersebut mengambil inisiatif dalam pembentukan Masyumi guna menyatukan golongangolongan Islam ke dalam satu partai politik yang kuat. ${ }^{22}$

Perkara-perkara besar yang dipandang sangat perlu dan mendesak dilakukan menurut para pembentuk Masyumi adalah menyikapi suasana "revolusi Indonesia" dan persaingan antara berbagai kelompok ideologi politik dalam

Is Partai-partai politik zaman pergerakan yang ikut serta para wakilnya seperti PSII, Partai Islam Indonesia (PII). Penyedar; sedangkan organisasi sosial keagamaan yaitu NU, Muhammadiyah, Persatuan Islam (Persis), PUI, PUI, dan sebagainya. Pada perkembangan berikutnya PSI keluar dari Masyumi pada 1947, menyusul NU pada 1952. Sekalipun begitu ada pula yang ikut meleburkan diri ke dalam Masyumi seperti Partaj "SERMI" (di Banjarmasin), Partai “USUMI" (di Samarinda), Al-Jamiyatul Wasliyah (di Medan), "Nurul Islam (di Tanjung Pandan), dan "Permi" (di Pontianak) pada 1950. Lihat, Taufiqurrahman, "Peringatan Ulang Tahun Ke V Partai Politik Islam 'Masyumi'", Suaro Partai Masyumi, 1950, No. 11, Th. 5, Desember, hal. 10; Amanat Prawoto Mangkusasmito, "Dalam Memperingati 6 Tahun Masyumi", Hikmah, 1951, No. 9 Th. IV, 4 November, hal. 6 dan penulis yang sama dalam "Amanat Wakil Kewa Pimpinan Partai Dalam Ulang Tahun Ke VI Masyuni", Suara Parai Masyumi, 1951. No. 11/12, Th. Ke-6, November-Desember, hal. 4; "Partai Masyumi" dalam Kepanaian di Indonesia, 1950, Jakarta: Kementerian Penerangan Republik Indonesia, hal. 9.

1 "Yusril Ihza Mahendra. 1999, Modemisme dan Fundamentalisme dalam Politik Islam: Perbandingan Parrai Masyumi (Indonesia) dan Pantai Jam ${ }^{-1} a r-i-I s l^{-} m \S$ (Pakistan), Penerbit Paramadina, Jakana, hal. 62-63.

in Pembahasan ini bisa dilihat dalam Tamar Djaja, 1952, "Masyumi dengan Anggota Istrmewa dan Oronom", Suara Partai Masyumi, No. 2, Th. Ke-7. Febnuari, hal. 27-28.

19 Yusril thza Mahendra, Modernisme dan Fundamenzalisme, hal. 64.

2n Ibid. hal. 65

${ }^{21}$ Mohammad Natsir dalam lbid.

$2 \mathrm{lbid}$. 
masyarakat Indonesia. ${ }^{23}$ Suasana revolusi dimulai sejak proklamasi kemerdekaan Indonesia pada 17 Agustus 1945 oleh Soekarno dan Mohammad Hatta. Suasana ini tampak mempengaruhi rumusan tujuan dan urgensi program Masyumi yang kelihatan sangat patriotik dan nasionalistik. Tujuan Masyumi pada Kongres Umat Islam itu adalah "Menegakkan kedaulatan Republik Indonesia dan Agama Islam," dengan senantiasa "Melaksanakan cita-cita Islam dalam urusan kenegaraan. ${ }^{n 4}$

Penjajahan yang dialami bangsa Indonesia, khususnya umat Islam, telah membawa penderitaan yang sangat berat. Kolonialis Belanda bersama Inggris yang datang seusai proklamasi kemerdekaan Indonesia, telah melakukan "provokasi-provokasi yang senantiasa diarahkan kepada daulat kekuasaan Republik Indonesia dan kemerdekaan bangsa dan Agama."25 Menurut Keputusan Muktamar Pertama Masyumi di Solo pada 1946, upaya imperialisme Belanda untuk menjajah kembali Indonesia, telah "memaksa... Umat Islam berjuang dalam cara Sabilillah, yakni meninggikan Kalimah Allah yang sedang direndah-hinakan dalam pergaulan waktu [revolusi] ini." ${ }^{26}$ Bagaimanapun, "Umat Islam di bawah pimpinan Masyumi... telah bulat niat dan tekadnya untuk tetap memiliki negara yang merdeka $100 \%$ dan oleh karenanya tidak akan menerima putusan dari siapapun juga yang tak dapat mencukupi tujuan Masyumi...."27 Usaha Masyumi untuk mewujudkan tekad tersebut ialah, pertama, dengan "peperangan kemerdekaan". Kedua, ikut dalam proses penyusunan pemerintahan yaitu anggota Masyumi terlibat di kabinet, parlemen dan jabatan-jabatan administrasi pemerintahan. Ketiga, "perjuangan diplomasi" di meja perundingan hingga dicapai pengakuan kedaulatan Indonesia oleh Belanda pada 7 Desember 1949. ${ }^{28}$

Pada usaha pertama, telah dibentuk "Barisan Hizbullah bagi para pemuda Islam dan Sabilillah bagi segenap Muslimin dan Muslimat. ${ }^{29}$ Terhadap usaha kedua, Masyumi mendukung perjuangan demokrasi untuk “...mewujudkan susunan negara yang berdasarkan kedaulatan Rakyat dan masyarakat berdasar keadilan menurut ajaran-ajaran Islam..." Perwujudan kedaulatan rakyat itu ditandai dengan “...adanya hak memilih dan dipilih yang umum dan langsung." 30 Usaha ketiga, selain untuk mendapat pengakuan internasional atas kedaulatan Republik Indonesia, Masyumi juga berupaya agar pemerintah

\footnotetext{
HIbid, hal. 66 .

${ }^{24}$ Lihat Anggaran Dasar Pasal II "Partai Masyumi” dalam Keparaian di Indonesia, hal. 10; dan Prawoto Mangkusasmito, "Dalam Memperingati 6 Tahun Masyumi", hal. 6.

Is "Dokumentasi Masyumi", I956 dalam Muktamar Masyumi Ke-VII 22-29 Desember, Panitia Muktamar Masyumi, Bandung VIII, 1956), hal. 28.

26 Ibid.

7 Ibid., hal. 29.

2* Yusril Thza Mahendra, Modemisme don Fundamentalisme, hal. 66, dan 78-81

29 Taufiqurrahman, "Peringatan Ulang Tahum Ke V", hal. 9; Abu Barkat, "Peristiwa Penting", hal. 16.

20 "Dokumentasi Masyumi", hal. 29-30.
} 
Indonesia menjalankan politik luar negeri bebas-aktif. ${ }^{31}$ Sikap politik Mar negeri Masyumi dipertegas oleh Manifest Politik 1947, bahwa Masyumi “...Berusaha supaya politik Umat Islam Indonesia dapat menempatkan Negara Republik Indonesia ... berdampingan dengan negara-negara Demokrasi, terutama yang berkuasa atau bepengaruh di Pasifik, dan menentang politik yang mungkin dapat merugikan haluan politik itu...."

Proses membentuk dan mempertahankan kedaulatan negara baru dalam suasana revolusi telah menimbulkan pertarungan kepentingan dari berbagai kelompok yang saling ber-saing memperebutkan kekuasaan dan pengaruh. Persaingan ini pada gilirannya melibatkan perta-rungan kelom-pok ideologi utama, yang telah lama tumbuh sejak awal zaman pergerakan yaitu kelompok Islam, Nasionalisme Sekular dan Komunisme. ${ }^{33}$

Persaingan aliran ideologi politik mendapatkan ruang geraknya, terutama setelah Maklumat Pemerintah yang ditandatangani Wakil Presiden Republik Indonesia Mohammad Hatta, pada 3 November 1945, tentang pembentukan partai-partai di Indonesia. Melalui maklumat itulah lahir partai-partai politik yang mewakili aliran-aliran ideologi-politik yang tumbuh di masyarakat. ${ }^{34}$ Bahaya persaingan ideologi politik ini dirasakan pula oleh Masyumi, sehingga dalam Manifest Politik 1947 ditegaskan perlu “... (2.) Menambah tersebarnya ideologi Islam di kalangan masyarakat Indonesia, dengan tidak menghalangi fihak lain yang sejalan mèmperkokoh sendi ke-Tuhanan Yang Maha Esa. (3.) Membentengi jiwa Umat Islam dari infiltrasi ideologi-ideologi yang bertentangan dengan Agama Islam dengan tekad fi-Sabilillah." 35

Latar ideologis Masyumi juga dipengaruhi oleh suasana internasional pascaPerang Dunia II, yang pada gilirannya melahirkan bentuk perang baru berupa "Perang Ideologi" yang kemudian dikenal dengan sebutan "Perang Dingin". Perang ini melibatkan dua kubu ideologi pemenang Perang Dunia II, yaitu Blok Barat yang terdiri atas Amerika Serikat dan negara-negara Eropa Barat memperjuangkan Kapitalisme, sedangkan Blok Timur yang terdiri atas Uni Soviet beserta negara-negara Eropa Timur memperjuangkan komunisme. ${ }^{36}$

Pertarungan dua kubu ideologi ini juga memiliki pengaruh terhadap keberpihakan politik internasional partai-partai politik di Indonesia masa revolusi tersebut. Bagi Masyumi, sebagaimana diulas di atas, lebih memilih

${ }^{31}$ Kebijakan politik luar negeri Masyumi dilegaskan benilang-ulang terutama dalam setiap kepurusan Muktamar sejak Muktamar I. Februari 1946.

32 "Dokumentasi Masyumi". hal. 29-30.

${ }^{33}$ Yusril thza Mahendra, Modernisme dan Fundomentalisme., hal. 67.

${ }^{34}$ Sekretariat Negara Republik Indonesia. 30 Tahun Indonesia Merdeka, PT Cítra Lamtoro Gung Persada, Jakanta, 1985. I: 55-56: George McTurnan Kahin, 1952, Narionalism and Revolution in Indonesia. Comell University Press. Ithaca, hal. 156-161.

35. "Dokumentasi Masyumi", hal. 33-34; Abu Barkat, "Peristiwa Penting", hal. 16.

${ }^{36}$ Fred Haliday, 1993, "Cold War" dalam Joel Krieger (ed.), The Oxford Companion to Politics of the World. Oxford University Press, New York dan Oxford, hal. 151-153. 
politik luar negeri bebas-aktif untuk tidak terikat dan memihak kepada salah satu dari kedua blok Perang Dingin. Menurut pernyataan Abu Hanifah, salah seorang anggota DPP Masyumi, dalam Muktamar V Masyumi di Jakarta pada 7-31 Januari 1951, bahwa “(8). - Politik bebas Indonesia, berarti mengalirkan politik luar negeri dengan aktif dan sedar kepada politik damai di dunia dan politik damai terhadap segala bangsa dan negara di Indonesia." 37 Politik luar negeri ini juga mensyaratkan adanya pengakuan internasional terhadap kedaulatan Republik Indonesia sebagai sebuah negara baru merdeka, sehingga terbina kerja sama di lapangan internasional untuk menciptakan kemakmuran, keadilan dan perdamaian dunia, terutama dengan negara-negara Islam. ${ }^{38}$ Dengan demikian, kondisi itu dapat terwujud apabila terdapat "kedudukan sama harga (sederajat) di antara bangsa-bangsa merdeka lainnya dalam pergaulan internasional." 39

\section{Islam di antara Kapitalisme dan Komunisme}

Pilihan Islam sebagai ideologi Partai Masyumi adalah sejalan dengan latar pembentukan Masyumi itu sendiri, sebagaimana telah diuraikan di muka. Cita Islam sebagai ideologi Masyumi tampak dari rumusan tujuan pertama kali yang diputuskan Kongres Umat Islam pertama di Yogyakarta, 7-8 November 1945, yaitu: "Pasal II. [1.] Menegakkan kedaulatan Republik Indonesia dan Agama Islam. [2.] Melaksanakan cita-cita Islam dalam urusan kenegaraan." 40

Tujuan Masyumi tersebut tampak didasari oleh pemikiran bahwa di dalam Islam tidak ada pemisahan antara urusan agama dengan urusan politik (negara). ${ }^{41}$ Dengan demikian, "menegakkan Islam tak dapat dilepaskan dari menegakkan masyarakat, menegakkan negara, menegakkan kemerdekaan." 42 Pemisahan antara agama dengan politik mungkin tepat bagi agama-agama lain di luar Islam, terutama pada agama Kristen (Katolik) yang mengenal teori "caesaro-papisme".43 Bagi Mohammad Isa Anshary, salah satu tokoh penting di Masyumi, pemikiran politik sekuler ini merupakan warisan " $c u l$ tural imperialism" yang dibawa oleh agen imperialis, yaitu kelompok "aliran kafir" (yang menolak kebenaran dan kenyataan agama), "aliran netral" yaitu kelompok paham nasionalisme (yang tidak mempedulikan agama) dan "aliran munafik" (yang lebih berbahaya daripada "aliran kafir").44

${ }^{37}$ Abu Hanifah, 1951, "Politik Luar Negeri", Stura Parai Masyumi, No. 2 Th. Ke-6, Februari, hal. 18.

3k "Dokumentasi Masyumi”, hal. 29.

$39 \mathrm{Jbid}$.

${ }^{4}$ Kepartaian di Indonesia, hal. 10

4l Mohammad Natsir. 1950. Islam sebagai Ideologi, cet. ke-2, : Penerbit Aida, Jakarta, hal. 14.

*2 Ibid., ha!. 7.

${ }^{43}$ Ibid., hal. 25.

4 M. Isa Anshary, 1953, "Garis Pokok Perdjuangan Masyumi (I)", Swara Parai Masyumi, No. 3, Th. VIII, Maret, hal. 18-19. 
Perkembangan berikutnya, penjelasan Islam sebagai ideologi Masyumi dipertegas dengan Tafsir Asas yang dipunuskan oleh Muktamar VI Masyumi di Jakarta, pada 24-30 Agustus 1952. Di dalam Tafsir Asas, tampak sekali sikap penolakan Masyumi terhadap kapitalisme yang diperjuangkan Blok Barat di bawah pimpinan Amerika Serikat dan komunisme yang diperjuangkan Blok Timur dengan pimpinan Soviet-Rusia. ${ }^{45}$ Baik kapitalisme maupun komunisme, keduanya adalah paham kebendaan (materialisme), "yang mengutamakan harta daripada manusia, dan oleh sifat dan tabiatnya menguatkan azas berebut hidup, dan memenangkan kekuatan daripada hak kebenaran" 46 sehingga dipandang "bertentangan dengan perintah dan ajaran Islam." 47

Dalam tinjauan Islam, menurut Sjafruddin "bukanlah komunisme yang akan menang, juga bukan kapitalisme, tetapi dalam pergolakan paham dan ideologi di masa sekarang ini, akhirnya Islamlah yang akan tampil ke muka dan bertindak sebagai juru-pisah,...." ${ }^{n 8}$ Alasannya, "Pertama: karena ajaranajaran dan sifat-sifat Islam. Kedua: berdasarkan sejarah Islam." 49

Sjafruddin Prawiranegara, salah seorang ideolog dan konseptor Tafsir Asas Masyumi, ${ }^{50}$ menyatakan bahwa "Islam merupakan kompromis antara komunisme dan Kapitalisme." ${ }^{\text {s1 }}$ Beberapa persamaan antara Islam dengan marxisme-komunisme adalah mengenai "keadilan sosial, pengakuan adanya kelas dan golongan di dalam masyarakat." 52 Persamaan inilah yang menyebabkan antara golongan komunis dan Islam dapat berdampingan melawan imperialisme-kapitalisme Belanda di zaman pergerakan, sehingga hampir sebagai suatu blok, "[keduanya]...tidak kelihatan siapa komunis yang tulen dan siapa kaum Muslimin yang asli. Berjoang bersama-sama, di[D]igulkan bersama-sama." 53

Dari beberapa persamaan, ternyata ada banyak perbedaan mendasar antara Islam dengan komunisme. Di antara perbedaan tersebut, antara lain, dapat dilihat pada persoalan perjuangan kelas dan pengakuan hak individual. Menurut Sjafruddin, Islam tidak menyetujui adanya perjuangan kelas seperti dianut kaum

49 "Tafsir Asas" dalam S.U. Bajasut (peny.), 1972, Alam Fikiran dan Djedjak Perdjuangan Prawoto Mangkusasmito, Documenta, Surabaya, hal. 401.

46 "Tafsir Asas", hal. 41. Lihat pula, Deliar Noer, 1987. Partai Islan di Pentas Nasional 1945-1965, PT. Pustaka Urama Grafiti, Jakarta, hal. 137-140.

47 "Tafsir Asas", Ibid.. Deliar Noer, Panai Islam, hal. 138.

4 Sjafruddin Prawiranegara, 1950, Islam dalam Pergolakan Dunia, Penerbit Al-Ma'arif, Bandung, hal. 11.

49 Sjafruddin Prawiranegara menambahkan dengan alasan ketiga yang bersifat subjektif yaim karena "...Tuhan sendiri telah berfiman bahwa Islam, atas pimpinan Rasulnya, adalah agama yang penghabisan." Ibid., hal. 12.

so Deliar Noer menyebutkan bahwa konseptor Tafsir Asas Masyumi selain Sjafnuddin Prawiranegara adalah Mohammad Natsir. Deliar Noer, Partai Islam., hal. 137.

"s Sjafruddin Prawiranegara, Islam dalam Pergolakan Dunia., hal. 13.

52 lbid.

s" Ibid., hal. 14-19. 
Marxis unnuk membela kaum lemah (proletar), dan tidak mungkin menghapuskan satu golongan satu golongan (kapitalis) tetapi hanya meringankan penderitaan kaum lemah, miskin dan tertindas dengan meletakkan tanggung jawab yang berat kepada golongan/kelas yang berkecukupan harta/materi. Terhadap individu, komunisme mengabaikan individualitas manusia, tetapi menitikberatkan kepada pertentangan-pertentangan di dalam masyarakat. Pada bagian lain, Sjafruddin Prawiranegara menjelaskan bahwa penghargaan terhadap potensi individual diakui oleh Kapitalisme, hanya saja penghargaan tersebut tidak ada batasnya, sehingga timbullah apa yang disebut dengan liberalisme-kapitalisme. ${ }^{54}$ Berbeda dengan Marxisme yang tidak mengakui individualitas, maka letak Islam adalah di tengahtengah antara Kapitalisme dan Marxisme. ${ }^{55}$

Terhadap kedua ideologi di luar Islam itu, Sjafruddin Prawiranegara sampailah kepada kesimpulan bahwa sebenamya "kapitalisme dan komunisme adalah identik".56 Keidentikan itu antara lain karena komunisme pun sebenarnya merupakan jenis lain kapitalisme, seperti yang tampak di Uni Soviet..$^{57}$ Selain itu, kapitalism̄e dan komunisme berasal dari atau sangat dipengaruhi oleh orangorang Yahudi. Sjafruddin mencontohkan bahwa Karl Marx adalah seorang keturunan Yahudi, di mana ayahnya seorang rabbi (pendeta Yahudi), sehingga "agama komunisme" direduksi menjadi sebagai bentuk pembaharuan agama Yahudi. ${ }^{58}$ Pendapat Sjafruddin ini tentu saja tidak begitu mengejutkan, tetapi kesimpulannya yang menyederhanakan sedemikian rupa antara Karl Marx yang keturunan Yahudi dengan pemikirannya yang kemudian đikenal sebagai Marxisme/' Komunisme adalah satu persoalan tersendiri. Tampaknya pendapatnya ini banyak dipengaruhi oleh situasi Perang Arab-Israel setelah berdirinya negara Israel pada bulan Mei 1948, di mana baik Amerika Serikat sebagai “agen utama kapitalisme” dan Uni Soviet sebagai "agen utama komunisme" sama-sama menyokong terbentuknya negara Israel.

Dalam penjelasan yang tidak jauh berbeda, menurut Mohammad Natsir keidentikan kapitalisme dan komunisme itu dapat dilihat pada masalah kebebasan manusia untuk mencapai kemakmuran, yaitu:

Komunisme dalam mencapai kemakmuran menekan dan memperkosa tabiat dan hak-hak asasi manusia. Sedang kapitalisme dalam memberikan kebebasan kepada tiap-tiap orang, tidak mengindahkan perikemanusiaan dan hidup dari pemerasan keringat orang lain dan membukakan jalan untuk kehancuran kekayaan alam..$^{59}$

\footnotetext{
st Ibid. . hal, 29-30.

ss Ibid. hal. 29.

So Ibid. hal. 40.

s7 pid. hal. 28-29.

31 Bahasan ini lihat Bid. hal. 36-41 .

59 Mohammad Nasir, 1952, "Djawab Kita", Swarc Partai Masyumi, No. 1 Th. Ke-7, Jamsari, hal. 5. Huruf miring sesuai dengan teks aslinya.
} 
Untuk itu, menurut Natsir, umat Islam perlu menjawab persoalan dari akibat kedua ideologi dunia yang dianggap telah menjajah umat Islam selama berabad-abad, dengan ajaran-ajaran Islam. Sebagai agama fitrah, Islam memberikan tuntunan hidup yang lengkap, serta memberikan kebebasan dan menyuruh manusia berusaha mencari nafkah dan kekayaan sekuat-kuatnya baik di laut maupun di darat. ${ }^{60}$

Terhadap pemilikan harta, misalnya, Natsir berpendapat bahwa manusia diberi kebebasan untuk berikhtiar secara ihsan, melakukan hak dan kewajiban secara berimbang, dan tidak dipakai sebagai alat pemuas nafsu. Untuk itu Natsir memandang perlu kewajiban zakat sebagai cara membangun kemakmuran seluruh masyarakat. Dengan mengorganisasi zakat secara baik, maka dapat dihilangkan kemiskinan dan kemelaratan di dalam masyarakat. Dengan cara ini, jelas sekali berbeda dengan komunisme, "Islam mengakui hak kepribadian dan memberikan kebebasan, bahkan mewajibkan kepada tiap-tiap orang supaya mencari rezki sekuat tenaga...."61 Sebaliknya berbeda dengan Kapitalisme, dalam Islam “...kekayaan yang didapat tidaklah boleh digunakan untuk kepentingan diri sendiri saja, tetapi harus pula dikeluarkan untuk menolong sesama manusia, guna menciptakan kemakmuran bersama."62 Dari uraian di atas, baik Sjafruddin Prawiranegara ataupun Mohammad Natsir nampak berpikir apologetik dengan memandang kelebihan-kelebihan di dalam pemikiran kapitalisme dan komunisme juga terdapat di dalam dan dicitacitakan Islam. Tetapi di sisi lain keduanya memandang kapitalisme dan komunisme memiliki kelemahan-kelemahan mendasar dihadapkan dengan prinsip-prinsip Islam. Dari cara yang demikian, wajar saja ápabila George McTurnan Kahin ${ }^{63}$ mengelempokkan keduanya - terutama Sjafruddinsebagai tokoh "sosialis-religius" di Masyumi.

Dari pertarungan ideologi antara Islam dengan komunisme dan kapitalisme, maka tugas dan kewajiban Masyumi adalah: pertama, mempertahankan kedaulatan Repub-lik Indonesia yang telah diprokla-masikan oleh bangsa Indonesia pada 17 Agustus 1945, yang telah menda-pat pengakuan internasional, dan mengisinya dengan melaksanakan ajaran-ajaran Islam di dalam kehi-dupan perseorangan, masyarakat dan negara Republik Indonesia menuju keridaan Ilahi. Untuk hal ini, maka Masyumi akan berjuang dengan jalan yang sah dalam negara Republik Indonesia yang berdasar kedaulatan rakyat, melalui jalan demokrasi. ${ }^{64}$

\footnotetext{
"sid.

"I Ibid. Huruf miring sesuai dengan teks aslinya.

6. Ibid. Huruf miring sesuai dengan teks aslinya..

43 George McTurnan Kahin, Narionalism and Revolurion, hal. 309-311.

in "Tafsir Asas", hal. 411-413.
} 
Kedua, mengingatkan umat manusia agar kembali kepada Tuhan dari kekeliruan komunisme dan kapitalisme dengan menjunjung tinggi kemerdekaan agama dari tekanan dan tindasan siapa pun. Masyumi akan bekerja sama dengan pihak mana pun di luar Masyumi sepanjang berpegang kepada kebenaran dan Qur'an. ${ }^{65}$ Ketiga, menolak kekerasan dalam penyelesaian konflik. Perihal politik dalam negeri, Masyumi menolak jalan paksaan dan sewenang-wenang, dan lebih memilih sarana hukum untuk menengahi setiap konflik. Terhadap hubungan internasional, Masyumi tidak membenarkan suatu bangsa menggunakan kekerasan, paksaan dan perkosaan untuk mengakhiri konflik terhadap suatu bangsa lainnya. ${ }^{66}$

\section{Sosialisme-Religius dan Sosialisme-Marxian}

Pada masa revolusi, cara pandang yang negatif terhadap kapitalisme banyak dianut sejumlah pemimpin Indonesia karena kapitalisme diangap sebagai penjelmaan dari penjajahan Belanda. Aspek negatif kapitalisme dapat dilihat dari pandangan mereka yang berdasarkan kritik Marxis-Leninis. ${ }^{67} \mathrm{Hal}$ ini berakibat pada anggapan pihak luar negeri terhadap rakyat dan pemerintah Indonesia yang dianggap terpengaruh Moskow (komunisme), sekalipun bagian terbesar rakyat Indonesia adalah Muslim. Pada gilirannya anggapan ini berlanjut pada pemahaman bahwa "semangat Islam di Indonesia sangat suka dengan paham-paham komunisme dan sosialisme." ${ }^{68}$ Padahal, "...bagi orang Amerika dan Philipina, komunisme dan sosialisme itu dipandang setali tiga uang. ....anggapan mereka itu memang tidak salah, apabila sosialisme itu diartikan sebagai sosialisme yang dianjurkan oleh Karl Marx. " 69

Masyumi sebagai partai yang mengklaim berideologi Islam menolak asumsi keliru tersebut. Sjafruddin Prawiranegara, sebagai fungsionaris DPP Masyumi, merasa perlu untuk meluruskan kekeliruan asumsi-asumsi yang mengatakan bahwa rakyat Indonesia yang mayoritas adalah Muslim telah dipengaruhi oleh komunisme. Pandangan keliru itu tampaknya lebih disebabkan oleh karena pemerintahan Indonesia di bawah kabinet Amir Sjarifuddin, serta parlemen (KNIP) sebagian besar didominasi Sayap Kiri dari Partai Sosialis. ${ }^{70}$

is tbid., hal. 415-417.

th Ibid., hal, 420-421.

${ }^{67}$ Herbert Feith, 1962, The Decline of Constitutional Democracy in Indonesia. New York, Ithaca, Cornell University Press, 35-36.

wN Sjafruddin Prawiranegara, 1948. Tindjauan Singkar tentang Politiek dan Revolusi Kita, Badan Penerbit Indonesia Raya, Yogyakara. hat. 4.

6" Ibid.

7n Sayap Kiri dari Partai Sosialis berubah menjadi "Front Demokrasi Rakyat" yang menjadi penopang utama PKI dalam Pemberontakan Madiun 18 September 1948. Kelompok lainnya di bawah Sjahrir memisahkan diri dengan membennuk Partai Sosialis Indonesia (PSI). Ibid., hal. 5. Lihat pula, bagian "3. Pemerintahan Sayap Kirir dalam Soe Hok Gie, 1997, Orang-Orang di Persimpangan Kiri Jalan: Kisah Pemberoneakan Madiwn September 1948. Yayasan Bentang Budaya, Yogyakarta, hal. 65-126; Herbert Feith, The Decline of Constitutional Democrocy, hal. 129. 
Pada masa revolusi bisa terjadi di antara Kaum Komunis dan Sosialis Indonesia adalah pemeluk agama yang taat, baik Islam maupun Kristen. Inilah yang mengherankan, sehingga Sjafruddin pun bertanya, "siapakah yang benar: merekakah [Muslim atau Kristiani] dengan menamakan dirinya sosialis atau komunis, atau saya dengan mengikut Partai Politik Islam Masyumi [?] "71 Menurut Sjafruddin, ada perbedaan antara Marxisme dengan agama manapun juga. Perbedaannya adalah bahwa dasar-dasar Marxisme adalah materialisme-historis yang sama sekali bertentangan dengan paham Ketuhanan dari tiap-tiap agama. ${ }^{2}$

Penjelasan berikutnya dari Sjafruddin adalah perbedaan antara sosialismemarxian yang berdasarkan materialisme-historis dengan sosialisme berdasarkan agama, yang disebut "Sosialisme-Religius." Ajaran-ajaran Marxisme seolaholah ada kemiripan dengan ajaran-ajaran Islam. Contohnya, perkataan yang mengajarkan "Kerjakanlah duniamu seolah-olah kamu akan hidup selamalamanya. ... seolah-olah merupakan suatu dalil daripada marxisme," padahal Islam melanjutkannya dengan kalimat "...dan kerjakanlah akhiratmu seolaholah kamu akan mati esok hari."73

Pandangannya terhadap suasana revolusi nasional di Indonesia, Sjafruddin tidak membedakan antara revolusi nasional dengan revolusi sosial sebagaimana dipertentangkan oleh kaum sosialisme-marxian. Tujuan dari revolusi bangsa Indonesia adalah keadilan sosial, yaitu keadilan sosial dalam arti “...suatu system masyarakat, suatu cara susunan politik dan ekonomi yang dapat menjamin terlaksananya keadilan sosial, kemakmuran rakyat dan sebagainya, yang tak dapat dicapai dalam zaman...system kolonial-kapitalis Belanda."74

Di dalam revolusi nasional pun terdapat unsur sosialisme, sebagaimana disebut dalam Pasal 33 ayat (1-3) Undang-Undang Dasar (UUD 1945). Namun, sosialisme menurut UUD berbeda dengan sosialisme-marxian. Hal itu tampak pada rumusan Pasal 29 ayat (1) yang menyatakan bahwa, "Negara berdasar atas Ketuhanan Yang Maha Esa", sedangkan Marxisme berdasarkan kepada materialisme-historis, yang menolak adanya Tuhan, serta mengajarkan perjuangan kelas antara kelas proletar dengan kelas kapitalis secara sangat kejam dan tidak berperikemanusiaan. Oleh karena sama sekali tidak ada pertalian batin antara sosialisme dalam UUD dengan sosialisme-marxian, maka tujuan revolusi nasional tak mungkin dapat dipenuhi oleh marxisme. ${ }^{75}$

Dengan mengambil kebaikan-kebaikan dari sosialisme-marxian dalam kolektivisme lapangan ekonomi, sosialisme-religius justru mengakui individualisme, inisiatif dan pertanggungjawaban perseorangan berdasarkan

\footnotetext{
"Sjafruddin Prawiranegara, Politiek dan Revolusi Kira, hal. 6.

"Ibid., hal. 6-7.

3 Ibid., hal. 9

${ }^{74}$ Ibid., 14.

7s Ibid., hal. 14-16
} 
nilai-nilai ketuhanan. Dari sini tampak bahwa visi sosialisme-religius dalam mengisi revolusi nasional adalah dengan menjamin:

...kemerdekaan seluruh bangsa, tetapi juga kemerdekaan bagi tiap-tiap orang, baik kemerdekaan berpoliti, maupun kemerdekaan berusaha dan berniaga,...atas dasar permufakatan, mengadakan sosialisasi, atau nasionalisasi terhadap beberapa perusahaan, yang dipandang perlu untuk kepentingan bangsa dan negara. ... revolusi nasional kita ini mengandung
terang-terangan anasir-anasir sosialisme, mempunyai sifat-sifat serupa dengan marxistis sosialisme. ${ }^{76}$

Secara singkat, sosialisme-religius dalam revolusi nasional tidak mendasarkan kepada materialisme-historis yang dianut sosialisme-marxian, tetapi disandarkan kepada kewajiban manusia terhadap sesama manusia, dan kewajiban manusia terhadap Tuhannya. Konsekuensi logis dari pandangan sosialisme-religius ini adalah bahwa “...sosialisasi atau nasionalisasi...berbagai alat produksi dalam masyarakat itu,... [bukan] merupakan tujuan yang terakhir melainkan hanya merupakan suatu alat untuk mewujudkan keadilan sosial atau kemakmuran rakyat." "7 Adapun sosialisme-marxian, untuk melakukan sosialisasi dan nasionalisasi alat produksi dipergunakan cara kekerasan dengan "membasmi suatu kelas atau golongan,"78 sebagaimana umum dituduhkan terhadap pengikut komunis yang sering lazim mempergunakan "tujuan menghalalkan berbagai cara".

\section{E. Fatwa Anti-Komunisme}

Penggunaan kekerasan sebagai implementasi dari "tujuan menghalalkan segala cara" seperti dianut sosialisme-marxian yang-menjadi paham golongan Komunis, dalam pandangan Masyumi jelas tidak dapat diterima dan sangat berbahaya terutama bagi pencapaian tujuan Masyumi itu sendiri. Karena sangat. berbahaya inilah, maka Majelis Syura Pusat Masyumi mengeluarkan fatwa tentang hukum Islam terhadap komunisme, yang diputuskan pada Muktamar VII Masyumi pada 3-7 Desember 1954 di Surabaya.

Fatwa Majelis Syura Masyumi antara lain mengatakan bahwa komunisme menurut hukum Islam adalah "kufur". Bagi orang yang menganut komunisme dengan pengertian, kesadaran dan meyakini kebenaran paham komunisme, maka hukumnya adalah "kafir". Seseorang yang mengikuti komunisme atau organisasi komunis dengan tanpa pengertian, kesadaran dan keyakinan atas hakikat falsafah, ajaran, tujuan dan cara-cara perjuangan komunis, maka hukumnya adalah "sesat". ${ }^{79}$

7h bid. hal. 16. Huruf miring dan cetak tebal sesuai dengan teks aslinya.

" lbid., hal. 16-17. Huruf cerak tebal sesuai dengan teks aslinya.

I Ibid.

79 Putusan Kongres P.P.I. Masyumi Ke-VT tanggal 3 s/d 7 Desember 1954 dan Farwa 'Alim Ulama Madjlis Sjura Pusat, 1955, Cet. Ke-2, Pustaka Sedia, Medan, hat. 12. 
Fatwa Majelis Syura Masyumi tersebut dilandasi oleh kenyataan-bahwa komunisme "sepanjang sejarahnya adalah BERTENTANGAN, MENENTANG DAN MEMUSUHI HUKUM SYARIAT ISLAM SERTA UMAT ISLAM." $"{ }^{0}$ Secara ringkas aspek-aspek komunisme yang bertentangan dengan Islam menurut fatwa tersebut dapat diikhtisarkan dalam Tabel I.

Sebelumnya, Majelis Syura Masyumi Jawa Barat juga telah mengeluarkan semacam "fatwa" yang sangat tegas, pada 24 Oktober 1954. Secara rinci pernyataan tersebut adalah sebagai berikut:

Setelah mempelajari secara mendalam dan membahas secara luas selukbeluk ideologi komunisme-marxisme baik dari sudut keagamaan, kepercayaan dan Ketubanan dimana jelas ajaran atau ideologi komunisme itu antiTuhan (atheisme) dan antiagama, maupun dari sistem politik kenegaraan dan ekonomi dimana terang ajaran dan ideologi komunisme itu anti-dernokrasi dan penghapusan hak milik perseorangan, dan dalam perikatan kemasyarakatan komunisme menganjurkan perjuangan kelas dan perang golongan;

MENGINGAT, bahwa ajaran dan ideologi komunisme-marxisme itu bukan saja bertentangan seluruhnya dengan ajaran dan hukum Islam, akan tetapi merupakan bahaya dan bencana besar bagi kehidupan keagamaan pada umumnya dan mengancam keselamatan Negara Republik Indonesia yang berdasar Ketuhanan Yang Maha Esa;

MENIMBANG, sudah seharusnya umat Islam terutama para 'Ulama dan Zu'ama Islam bersikap tegas terhadap aliran dan keyakinan (ideologi) komunisme-marxisme, sesuai dengan ajaran Islam (Qur'an dan Hadis): bahwa adalah kewajiban hukum bagi umat Islam Indonesia menyelamatkan Negara Republik Indonesia dan umat bangsa kita dari bahaya komunisme itu;

MENDENGAR, pemandangan-pemandangan dan pembicaraan para utusan yang berdasar kepada nash Al-Qur'an dan Hadits dalam konferensi tersebut di atas;

\section{MEMUTUSKAN:}

1. Ideologi Komunisme adalah satu ideologi yang sangat bertentangan dengan ajaran dan hukum Islam, dan merupakan bahaya besar bagi kehidupan Agama dan Negara Republik Indonesia;

2. Umat Islam yang menganut ideologi komunisme terang MURTAD dari agama Islam;

3. Haram hukumnya umat Islam masuk menjadi anggota Partai Komunis Indonesia dan Partai-Partai dan organisasi-organisasi yang sudah terang hendak menegakkan hukum dan ideologi komunisme di Indonesia;

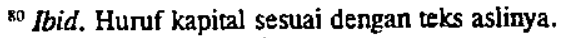


4. Kalau ada orang yang menganut paham Komunisme (PKI) yang meninggal dunia, tidak wajib disembahyangkan dan dikuburkan secara Islam;

5. Menyetujui berdirinya "FRONT ANTI KOMUNIS" yang dibentuk oleh para pemimpin "Masyumi" Jawa Barat, dan menganjurkan kepada segenap kaum Muslimin seluruh Indonesia supaya membentuk "FRONT ANTI KOMUNIS" di daerah-daerah masing-masing, sebagai pernyataan pendirian tegas dan tantangan perlawanan terhadap ideologi komunisme;

6. Bersikap diam terhadap aliran dan ideologi komunisme yang diperjuangkan oleh Partai Komunis Indonesia (PKI) berarti membiarkan dan ridla berkembang dan berkuasanya satu ideologi yang sangat dimurkai oleh Allah swt.

7. Menyerukan kepada segenap umat Indonesia terutama para 'Ulama dan Zu'amma Islam agar melaksanakan ajaran Islam, ialah membentuk front persatuan Islam yang kuat dan kukuh, guna membendung aliran dan ideologi yang membahayakan itu;

8. Menyerukan kepada segenap aliran partai-partai politik yang antikomunis, agar mereka menghentikan kerja sama mereka dengan Partai Komunis Indonesia.... ${ }^{81}$

\section{TABEL I}

\section{Aspek-aspek Ajaran Komunisme yang Bertentangan dengan Islam ${ }^{k 2}$}

\begin{tabular}{|c|c|}
\hline ASPEK-ASPEK AJARAN KOMUNISME & ALASAN BERTENTANGAN DENGAN ISLAM \\
\hline $\begin{array}{l}\text { 1. Komunisme adalah falsatah yang berdasarkan } \\
\text { materialisme-historis (paham kebendaan } \\
\text { berdasarkan sejarah). }\end{array}$ & $\begin{array}{l}\text { Ajaran Islam menyatakan bahwa Yang Menjadikan dan } \\
\text { memberi segala sesuatu, baik berwujud kebendaan } \\
\text { maupun kerohanian adalah Allah (QS. 45:22; 25:2; } \\
20: 50 ; 18: 84 ; 4: 78 \text { ). }\end{array}$ \\
\hline $\begin{array}{l}\text { II. Komunisme memusuhij agama dan } \\
\text { mengingkari adanya Tuhan (Atheisme). }\end{array}$ & $\begin{array}{l}\text { Ajaran Istam mengakui adanya Allah dan mengakui } \\
\text { adanya agama-agama (OS. 2:28; 109:6; 10:99) }\end{array}$ \\
\hline $\begin{array}{l}\text { III. Komunisme melenyapkan ikatan keluarga dan } \\
\text { menjadikan wanita milik bersama. }\end{array}$ & $\begin{array}{l}\text { Ajaran Isiam memelihara dan mengatur serta } \\
\text { menganggap suci ikatan keluarga dan perkawinan serta } \\
\text { mengharamkan perinaan (QS. 4:3; 17:32; 8:75; 47:22). }\end{array}$ \\
\hline $\begin{array}{l}\text { N. Kominisme pada dasamya melenyapkan hak } \\
\text { milik perseorangan atas alat-alat produksi dan } \\
\text { kekayaan. }\end{array}$ & $\begin{array}{l}\text { Ajaran Islam pada dasarnya mengakui hak milik } \\
\text { persecrangan atas alat-alat produksi dan kekayaan, asal } \\
\text { diperoleh dengan cara yang halal, Atas hak milik ada } \\
\text { batas-batas kewajibannya serta dapat diatur dan dipimpir } \\
\text { untuk kepentingan umum (QS. 13:26; 4:31; } 51: 19 ; 2: 219 ; \\
\text { 9:34; dan Hadis Nabi di Haji Perpisahan [Wada] artinya: } \\
\text { "Sesungguhnya darah kamu dan harta kamu haram } \\
\text { diganggu sampai kamu menghadap Tuhanmu, seperti } \\
\text { sucinya har dan bulan Haji ini."). }\end{array}$ \\
\hline $\begin{array}{l}\text { V. Komunisme memperjuangkan dan } \\
\text { melaksanakan cita-citanya dengan sistem } \\
\text { diktator-proletar. }\end{array}$ & $\begin{array}{l}\text { Ajaran Islam menganjurkan syura, antara segala } \\
\text { golongan rakyat (QS. 42:38; 3:159). }\end{array}$ \\
\hline
\end{tabular}

"1 "Pernjataan Madjlis Sjura, 1954, 'Masyumi' Djawa Barat", Aliran Islam, No. 65. Th. VII. OktoberNovember-Desember, hal. 56-57.

2 Diringkas dari Putusan Kongres P.P.I. Masjwni Ke-V, hal. 2-12. 
Sejalan dengan Fatwa Majelis Syura Masyumi, M. Isa Anshary, fungsionaris DPP Masyumi dan aktivis Front Anti Komunis, memperinci bahaya komunisme bagi umat Islam. ${ }^{83}$ Bahaya tersebut: pertama, bahwa komunisme dibangun atas filsafat hidup yang belum selesai, yaitu materialisme-histori, yang bertentangan sama sekali dengan fitrah kemanusiaan dan aturan alam besar ini. Kedua, materialisme ini pada dasarnya adalah menolak adanya Tuhan, wahyu dan Nabi. Ketiga, implikasi penolakan adanya Tuhan adalah komunisme menjadi anti-agama. Keempat, implikasi materialisme-histori adalah berlakunya hukum rimba dengan adagium “Apa yang dapat kau rampas itulah hakmu!” Kelima, komunisme dibangun tanpa moral karena moral kesusilaan hanyalah pagar bagi kaum borjuis untuk mengekalabadikan kekuasaannya. Keenam, marxisme mempergunakan pertentangan antarkelas (perang golongan) yang berbeda untuk mencapai tujuannya, yaitu masyarakat tanpa kelas. Ketujuh, kekuasaan diktator-proletariat pada dasarnya adalah pemerintah teror yang didasarkan kepada kekuatan, ancaman dan ketakutan serta tegak dengan penuh kecurigaan dan kecemburuan antar kelas. Kedelapan, komunisme merupakan "neraka dunia" karena tidak diakuinya hak milik perseorangan ditiadakan dengan jalan paksa-kekerasan, sehingga manusia sebagai pribadi terampas kemerdekaannya. Kesembilan, komunisme pada dasarnya anti-demokrasi karena tidak diakuinya perbedaan tafsir dan kebebasan berpendapat. Kesepuluh, komunisme adalah antinasional karena berkiblat dan mengabdi kepada kepentingan Moskow sebagai induk komunisme dunia. Kesebelas, komunisme pada dasarnya adalah imperialisme baru karena revolusi dunia yang diidamidamkan oleh kaum komunis bertujuan untuk melaksanakan penjajahan baru atas umat manusia dengan cara menggulingkan tiap-tiap kekuasaan bukan komunis. Terakhir, komunisme adalah merupakan penjelmaan "agama palsu" karena komunisme atau Marxisme tidak terbatas pada epistemologi materialisme-histori dalam persoalan kehidupan dan kemasyarakat-an manusia belaka, kaidah-kaidah perekonomian dan pembagian rezeki, tetapi juga berperan seperti "agama baru" yang memutarbalikkan pandangan hidup manusia. Agama komunisme ini disebut sebagai "agama kebencian" karena hendak memutarbalikkan wajah dan semangat manusia dari menuhankan Tuhan yang Gaib kepada menuhankan tuhan yang nyata (konkret), alam materi.

\section{F. Faksi Masyumi Menghadapi Komunisme}

Penyikapan terhadap wacana Komunisme di dalam tubuh Masyumi sedikitnya melahirkan dua faksi utama, yaitu faksi Sukiman Wirjosandjojo dan faksi Natsir. ${ }^{84}$ Di luar kedua faksi tersebut, ada faksi Muhammad Isa

\footnotetext{
Diringkaskan dari M. Isa Anshary, 1954, “Islan Menanang Komunisme”, dalam Bahaja- Merah di Indonesia, Front Anti Komunis, Bandung, hal. 4-24.
} 
Anshary yang dikenal sangat radikal dan ekstrim. Faksi-faksi tersebut-memiliki tanggapan berbeda terhadap komunisme, meskipun sama-sama menolaknya.

Jusuf Wibisono, ${ }^{85}$ sebagai salah seorang yang tergolong ke dalam faksi Sukiman, menyatakan bahwa kewajiban bagi umat Islam Indonesia untuk mengenal lebih dekat Marxisme supaya dapat menyelidiki lebih seksama seberapa jauh perbedaan, kesearahan/satu jalan, dan pertentangannya dengan Islam. Dengan mengenal aliran Marxisme itu, maka dapat dikurangi kesalahpahaman yang tidak perlu, yang merugikan perjuangan Islam sendiri. Pada gilirannya, sikap demikian akan menumbuhkan penghargaan terhadap anasir-anasir yang dianggap berguna dan dapat memperkaya pengetahuan para kader politik Masyumi.

Dari kelompok radikal, Muhammad Isa Anshary, anggota Masyumi dari Persis, adalah salah satu contoh yang sering disebut "ekstrimisme Muslim". Isa Anshary membidikkan semua upaya untuk memperluas dan memanfaatkan isu antikomunisme sebagai senjata politik utama. Kemudian Isa Anshary membentuk organisasi Front Anti Komunis pada tahun 1953. Front ini merupakan pengembangan dari rencana pembentukan "Front Ketuhanan dan Demokrasi" pada tahun 1952. Menurut Isa Anshary, ia merasa bahwa pertumbuhan komunisme di Indonesia merisaukan sejak masa itu. Ia menuntut sikap antikomunis yang "lebih tegas", sehingga dipilihlah nama "Front AntiKomunis" ${ }^{87}$ Organisasi bentukan Isa Anshary ini tidak ada kaitan formal dengan Masyumi, ${ }^{88}$ tetapi oleh sebagian tokoh Masyumi dianggap sebagai kelompok penekan yang ditujukan kepadanya.

Berbeda dengan kelompok radikal, Kelompok moderat yang cenderung ditujukan kepada faksi Sukiman, jauh dari "lunak" dalam pikiran mereka tentang Komunisme di Indonesia. Kalaupun cenderung menentang cara-cara Isa Anshary dan menganggapnya rawan serta berbahaya, bukan berarti merekamengamati pertumbuhan komunisme secara pasif. Dalam melawan komunisme, mereka mengutamakan pengembangan suatu program partai yang praktis. Oleh Compton, ${ }^{89}$ perbedaan dalam tubuh Partai Masyumi tersebut bukan mengenai persoalan "apakah harus memerangi komunisme", melainkan

44 Abu Hanifah, salah seorang anggota DPP Masyumi, mengelompokkan faksi Masyumi menjadi tiga golongan, yaius faksi konservatif, moderat dan sosialis-religius. Pembagian Abu Hanifah kelihatan agak aneh ketilea memasukkan Natsir, Sjafruddin dan Roem ke dalam faksi moderat, sedangkan Sukiman dan Jusuf Wibisono, dan dia sendiri ke dalam faksi sosialis-religius. Untuk inu penulis lebih sependapat dengan George Kahin, yang memasukkan faksi Natsir-Sjafruddin sebagai kelompok sosialis religius. Lihat, George MeTuman Kahin. Nationalism and Revolusion, hal. 309-311: Ahmad Syafí Maarif, 1987, Islam dan Masalah Kentegaraan: Srudi tentang Percaturan dalam Konstinuante, Cet. ke-2, LP3ES, Jakarta, hal. 113.

susuf Wibisono, 1951, Islam dan Sosialisme, Cet. II, Pustaka Islam, Jakarta, hal.I: 4.

"6 Boyd R. Compton, 1993. Kemelut Demokrasi Liberal: Surat-Surat Rahasia, LP3ES, Jakarta, hal. 210

Ibid, hal. 211

Ibid, hal. 215

${ }^{89}$ Ibid, hal. 210-211 
"bagaimana harus memerangi komunisme".

Sikap faksi Natsir yang dikenal sebagai kelompok sosialis religius dalam Masyumi antara lain dapat dilihat dari Urgensi Program Masyumi pada awal 1946, yang kemudian dijelaskan oleh Sjafruddin Prawiranegara dalam buku Politiek dan Revolusi Kita ${ }^{90}$ yang diterbitkan pada pertengahan 1948, dan dalam Tafsir Azas Masyumi pada 1952 yang konsepnya disusun bersamasama Mohammad Natsir. Sjafruddin berpendapat bahwa dasar sosialisme Masyumi berbeda dengan sosialisme yang dianut kaum Komunis (Marxis), sekalipun mirip dengan Sosialisme-Marxian. Sosialisme-Religius tidak didasarkan pada materialisme historis Karl Marx, tetapi dasarnya kepada tugas manusia terhadap sesamanya dan tugas manusia kepada Tuhannya. Selain itu, perbedaan mencolok tampak pada soal perjuangan kelas yang dipergunakan Sosialisme Marxian yang cenderung menjadi Fasis karena semua ditujukan untuk negara sebagai bentuk kolektivitas, sedangkan Sosialisme Religius hanyalah salah satu alat untuk mewujudkan keadilan sosial dan kemakmuran rakyat.

Sikap kelompok sosialis-religius ini makin keras terhadap komunisme ketika ide Demokrasi Terpimpin mulai dikenalkan Presiden Soekarno pada akhir 1956. Di bawah gagasan ini, PKI dapat merangkul Soekarno untuk melempangkan jalan komunisme di Indonesia. ${ }^{91}$ Sikap keras ini tampak sekali ketika Mohammad Natsir, Sjafruddin Prawiranegara, dan Burhanuddin Harahap turut bergabung dengan PRRI (Pemerintahan Revolusioner Republik Indonesia), yang diproklamasikan pada 15 Februari 1958 di Padang, yang sejalan dalam melihat ancaman komunisme (PKI).$^{92}$ Keterlibatan mereka di dalam PRRI kemudian menjadi alasan bagi Presiden Soekarno mengharuskan Masyumi bubar pada Agustus 1960.

\section{G. Penutup}

Dari uraian di atas menunjukkan bahwa wacana Masyumi terhadap Komunisme didukung oleh latar ideologis pembentukan Masyumi itu sendiri dalam konteks suasana revolusi dan persaingan ideologi politik setelah Proklamasi Kemerdekaan 17 Agustus 1945, serta situasi internasional Perang Dingin. Selain itu, konteks latar ideologis tersebut diterjemahkan dalam sistem penjelas sejumlah tafsir ideologis Islam dengan membandingkan keutamaan Islam sebagai ideologi di antara pergumulan Kapitalisme dan Komunisme. Sosialisme-religius yang dipahami Masyumi tampak berbeda dengan sosialisme

\footnotetext{
Lihat catatan kaki no. 55 di atas.

91 Uraian menarik perihal hubungan segitiga Presiden Soekamo, PKI dan Tentara, dapat dibaca: Herbert Feith, 1995, Soekamo-Militer dalam Demokrasi Terpimpin, terj. Tim PSH, Pustaka Sinar Harapan, Jakarta, hal. 42-49. dan 135-152.

2 Herbert Feith. The Decline of Constitutional Democracy, hal. 585-586.
} 
yang dipahami oleh kalanggan Marxis. Fatwa anti-komunisme yang diputuskan Majelis Syura Masyumi Pusat mencerminkan bahwa persoalan bahaya komunisme dicarikan rujukan teologisnya dari sumber Islam (Qur'an dan Sunnah) yang juga menjadi dasar perwujudan cita-cita Masyumi. Pada aras praktis, wacana ideologis Masyumi mengkristal dalam faksi-faksi Masyumi ketika menghadapi isu Komunisme.

\section{DAFTAR PUSTAKA}

Anshary, M. Isa.1953. “Garis Pokok Perdjuangan Masyumi (I)”. Dalam Suara Partai Masyumi. No. 3. Th. VIII. Maret

. 1954. "Islam Menantang Komunisme". Dalam Bahaja-Merah di Indonesia. Front Anti Komunis, Bandung

Barkat, Abu. 1951. "Peristiwa Penting Bagi Umat Islam Indonesia 17-81945 - 17-8-1951". Dalam Suara Partai Masjumi. No. 8-9. Th. Ke-6, November.

Compton, Boyd R. 1993. Kemelut Demokrasi Liberal: Surat-Surat Rahasia. LP3ES. Jakarta

Djaja, Tamar. 1952. "Masyumi dengan Anggota Istimewa dan Otonom", Dalam Suara Partai Masyumi. No. 2, Th. Ke-7, Pebruari

"Dokumnetasi Masyumi”. 1956. dalam Muktamar Masjumi ke-VII 22-29 Desember 1956. Panitia Muktamar Masjumi VIII. Bandung,

Eriyanto. 2001. "Sikap Mendua pada Gus Dur”. Jurnal Pantau. Edisi 10/Th. 2001.

Feith, Herbert. 1962. The Decline of Constitutional Democracy in Indonesia. Cornell University Press. Ithaca

. 1995. Soekarno-Militer dalam Demokrasi Terpimpin. penerjemah Tim PSH. Pustaka Sinar Harapan. Jakarta

Haliday, Fred. 1993. "Cold War" Dalam Joel Krieger (penyunting). The Oxford Companion to Politics of the World. Oxford University Press. New York dan Oxford

Hanifah, Abu. 1951. "Politik Luar Negeri”. Dalam Suara Partai Masyumi. No. 11-12. Th. Ke-6, Pebruari 
Kahin, George McTurnan. 1966. Nationalism and Revolution in Indonesia. Cornell University Press. Ithaca. Cet. ke-7

Keputusan2 M.P.R.S. Sidang Umum ke-IV 20 Djuni - 6 Djuli 1966. 1966. U.P. Indonesia. Yogyakarta

Maarif, Ahmad Syafii. 1987. Islam dan Masalah Kenegaraan: Studi tentang Percaturan dalam Konstituante. cet. ke-2. LP3ES. Jakarta

Mahendra, Yusril Ihza. 1999. Modernisme dan Fundamentalisme Politik Islam: Perbandingan Partai Masyumi (Indonesia) dan Partai Jam ' 'ati-Isl'm§ (Pakistan). Penerbit Paramadina. Jakarta

Mangkusasmito, Prawoto. 1951. "Amanat Wakil Ketua Pimpinan Partai Dalam Ulang Tahun Ke VI Masyumi”. Dalam Suara Partai Masyumi. No. 11/12, Th. Ke-6, November-Desember

. 1951. "Dalam Memperingati 6 Tahun Masyumi". Dalam Hikmah, No. 9 Th. IV, 24 November

Natsir, Mohammad. 1950. Islam sebagai Ideologi. Penerbit Aida. Jakarta Cet. ke-2.

1952. "Djawab Kita". Dalam Suara Partai Masyumi. No. 1 Th. Ke7 Januari

Noer, Deliar. 1987. Partai Islam di Pentas Nasional 1945-1965. PT. Pustaka Utama Grafiti. Jakarta

"Partai Masjumi". 1950. Dalam Kepartaian di Indonesia. Kementerian Penerangan Republik Indonesia. Jakarta

“Pernjataan Madjelis Sjura 'Masjumi' Djawa Barat”. 1954. Aliran Islam. No. 65. Th. VIII. Oktober-November-Desember.

Prawiranegara, Sjafruddin. 1948. Tindjauan Singkat tentang Politiek dan Revolusi Kita. Badan Penerbit Indonesia Raya. Yogyakarta.

. 1950. Islam dalam Pergolakan Dunia. Penerbit Al-Ma'arif. Bandung

Putusan Kongres P.P.I. Masyumi Ke-VII tanggal 3 s/d 7 Desember 1954 dan Fatwa 'Alim Ulama Madjlis Sjura Pusat. 1955. Pustaka Sedia. Medan. Cet. Ke-2.

Sekretariat Negara Republik Indonesia. 1985. 30 Tahun Indonesia Merdeka, PT Citra Lamtoro Gung Persada. Jakarta

“Seputar Penghapusan Tap MPRS No. XXV." 2000. Suara Merdeka. 8 April. 
Soe Hok Gie. 1997. Orang-Orang di Persimpangan Kiri Jalan: Kisah Pemberontakan Madiun September 1948. Yayasan Bentang Budaya. Yogyakarta

“Tafsir Asas". 1972. Dalam S.U. Bajasut (penyunting). Alam Fikiran dan Djedjak Perdjuangan Prawoto Mangkusasmito. Documenta. Surabaya Taufiqurrahman. 1950. "Peringatan Ulang Tahun Ke V Partai Politik Islam 'Masyumi'". Dalam Suara Partai Masyumi, No. 11, Th. 5, Desember

Wibisono, Jusuf. 1951. Islam dan Śsialisme. Pustaka Islam. Jakarta. Cet. ke-2. Jilid I 